\title{
The Effect of Claw Lesions and Claw Infections on Lameness in Loose Housing of Pregnant Sows
}

\author{
By H. Gjein' ${ }^{1}$ and R. B. Larssen ${ }^{2}$ \\ ${ }^{1}$ Norwegian Pig Health Service, Central Veterinary Laboratory, and ${ }^{2}$ Department of Large Animal Clinical Sci- \\ ences, Norwegian College of Veterinary Medicine, Oslo, Norway.
}

\begin{abstract}
Gjein, H. and R.B. Larssen: The effect of claw lesions and claw infections on lameness in loose housing of pregnant sows. Acta vet. scand. 1995, 36, 451-459. - During a 12-month period lameness, claw lesions and claw infections were studied in 15 herds with loose housing of pregnant sows on partly slatted concrete floors. Of these herds, 12 herds had concrete slats and 3 herds had plastic slats. The mean prevalence proportion of lame sows in the herds was $13.1 \%$. The risk of lameness increased with increasing claw lesion score and with the presence of claw infections. In the herds with concrete slats, the relative risk of lame sows was 2.4 times higher than in the herds with plastic slats. In the herds with poor floor hygiene, the relative risk of lameness was 2.8 times higher than in the herds with dry and clean floors. The mean prevalence proportion of sows with claw infections at the 3 separate examinations in the 15 herds was $3.8 \%$. Claw infections were more prevalent in herds with dirty floors and in herds with little space per animal $\left(<2 \mathrm{~m}^{2}\right)$. In the herds with concrete slats, the relative risk of claw infections was 2 times higher than in the herds with plastic slats.
\end{abstract}

pig; toe injuries; concrete slats; floor hygiene; area; epidemiology.

\section{Introduction}

Lameness is one of the main reasons for culling of sows in intensive sow housing (Dagorn \& Aumaitre 1979, Karlberg 1979, D'Allaire et al. 1987, Dewey et al. 1992, Gjein \& Larssen 1995 a). Lameness may be caused by osteochondrosis, osteomalacia, infectious diseases and lesions in musculature, bones, nerves, joints and claws (Hill 1992).

In a Dutch study $40 \%$ of the sows had painful claw lesions (de Koning et al. 1990), while in another study $80 \%$ of the cases of observed lameness were attributed to claw lesions (van der Meulen et al. 1990). Infections secondary to claw lesions may cause lameness. Claw infections easily spread upwards to the coronary band where swelling and abscess formation may occur (Penny et al. 1963, Penny et al. 1965, Wright et al. 1972, Simmins \& Brooks 1988). Infections primarily localized to the feet and legs may also spread to other tissues causing arthritis, osteomyelitis in the vertebral column, or abscesses in the lungs (Hoskin 1965, Penny et al. 1965).

Claw infections have been associated with a rough, dirty and wet floor surface. A dirty environment with a high level of pathogens on the floor surface may cause infection in a claw lesion and cause lameness (Fritschen 1979).

The aim of the present study was to examine the relationship between lameness, claw lesions and claw infections under different field conditions in loose housing herds with partly slatted concrete floors. 


\section{Materials and methods \\ Herds}

The study was carried out in 15 Norwegian herds with loose housing of pregnant sows. The average number of sow-year in these 15 herds was 39.2 (26-70). One sow-year is the equivalent of a sow older than 6 months that spends a complete year in the herd, however, only sows that subsequently farrow are included. All herds had partly slatted floors with very little bedding and electronic sow feeding, 12 herds had concrete slats, and 3 had plastic slats.

The 15 herds were a subgroup of herds from a larger investigation that compared claw health in 2 randomly sampled groups of 18 herds with loose versus confined housing of pregnant sows. The herds with confined housing were excluded from this study because lameness could not be properly examined in these herds. Three of the 18 herds with loose housing of sows were also excluded from the study. The 3 excluded herds had deep litter flooring that resulted in a completely different and better situation with regard to claw health (Gjein \& Larssen 1995 b, c).

For further details about design, management and selection of herds see Gjein \& Larssen (1995 a, b).

\section{Clinical examinations}

The hind legs of all sows were examined for lameness, lesions and infections at each of the 3 visits to the herds (October 1989, April 1990, October 1990). Examination for lameness was performed while the sows were walking or running. All sows that showed a sign of lameness of one of the hind legs were classified as lame. The claw lesions were divided into 6 different types and scored on a scale from 1 (normal) to 5 (very serious) as described in detail by Gjein and Larssen (1995 b). Claw lesions with score 3,4 or 5 were defined as major claw lesions. Claw infection was defined as present if swell-

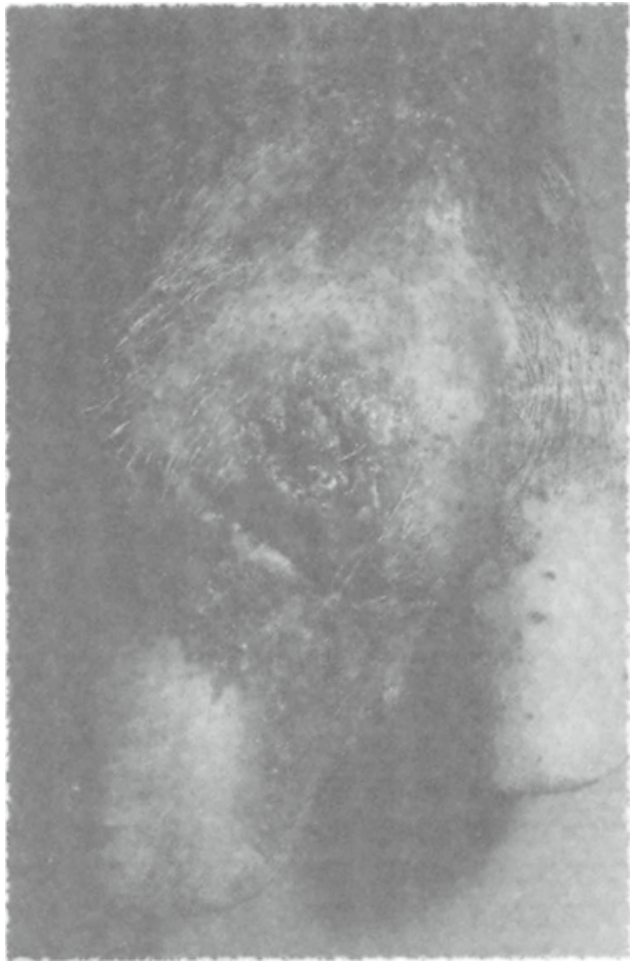

Figure 1. A sow with a serious claw infection.

ing or necrosis or ulceration was found on the claw or on the coronary band (Fig. 1).

\section{Environmental examinations}

Floor hygiene was scored as follows : Score 1 was good (dry and clean), score 2 was medium, and score 3 was poor (wet and dirty). The area per sow was measured in the loose housing compartment, and the type of slats was recorded.

\section{Statistical methods}

Unless otherwise stated, the following measures of disease on a herd level were used: Prevalence proportion $=$ The arithmetic mean of the prevalence proportion of sows with the lesion/disease in the herd at the 3 examinations. 
Cumulative proportion $=$ The cumulative proportion of sows in the herd that had the lesion/disease on at least 1 of the 3 examinations. Herd was used as unit in the statistical analysis except in the description of the relationship of lameness and claw infection with age (Fig. 2 and 4), and with time after farrowing and claw lesion score (Fig. 3, 5 and 6). In these presentations sow observation, i.e., each of the 3 examinations of the sows, was treated as an independent observation and was used as unit. No statistical hypothesis testing was performed using sow observation as unit since the observations were not statistically independent. However, the $95 \%$ confidence intervals (CI) of the group means are marked in Fig. 2, 3 and 4.

Relative risks with $95 \%$ CI (in Tables 2 and 3) were calculated using the Statcalc module in Epilnfo (Dean et al. 1990). All other analyses were made in Statistical Analysis System (SAS Institute Inc. 1989). The effects of environmental factors (Table 1) were analyzed both using simple one way ANOVA and using a multivariate model with all relevant factors in the model (PROC GLM in SAS). This model takes into consideration the influence of all the environmental factors simultaneously. Model specification for the GLM multivariate analysis for lameness (/claw infection) :

$\mathrm{y}=\mathrm{m}+\mathrm{ai}+\mathrm{bj}+\mathrm{ck}+\mathrm{eijk}$, where

$\mathrm{y}=$ mean herd prevalence of lameness (/claw infection)

$\mu=$ overall mean

$\mathrm{a}_{\mathrm{i}}=$ floor hygiene (1=good, $2=$ medium, $3=$ poor)

$b_{j}=$ area per sow $\left(1<2 \mathrm{~m}^{2}, 2 \geq 2 \mathrm{~m}^{2}\right)$

$c_{k}=$ slats $(1=$ concrete, $2=$ plastic $)$

$\mathrm{e}_{\mathrm{ijk}}=$ random error

\section{Results}

Lameness

The mean prevalence proportion of lame sows in the herds was $13.1 \%$, while the mean cumu- lative proportion of sows was $21.4 \%(6.9 \%$ $38.3 \%$ ). In the herds with poor and medium floor hygiene (Table 1), the relative risk of lame sows was 2.8 times higher than in the herds with good floor hygiene $(\mathrm{p}<0.05)$. The area per sow did not seem to have any influence on the risk of lameness. In the herds with concrete slats, the relative risk of lame sows was 2.4 times higher than in the herds with plastic slats $(\mathrm{p}<0.05)$.

The prevalence proportion of lame sows seemed to increase slightly with age from litter 0 to 2 (Fig. 2). However, the differences were not significant (all the $95 \%$ CI overlap), and there was no corresponding increase for older sows, i.e. litter $\geq 3$. The prevalence proportion of lame sows was slightly higher in the second and third month after farrowing, i.e. in the first time after the sows had come into the loose housing compartment (Fig. 3).

Nearly $40 \%$ of the sows with the most serious claw lesions (score $=5$ ) were lame (Fig. 5).

\section{Claw infection}

The mean prevalence proportion of sows in the herds with claw infection was $3.8 \%$, while the mean cumulative herd proportion of sows that had claw infection was $5.9 \%(0 \%-12.8 \%)$. In the herds with poor floor hygiene, the relative risk of claw infection was 4.2 times higher $(\mathrm{p}<$ 0.05 ) than in the herds with good floor hygiene (Table 1). In the herds with small area per pregnant sow $\left(<2 \mathrm{~m}^{2}\right)$, the relative risk of getting claw infection was 2.1 times higher $(\mathrm{p}<0.05)$ than in the herds with large area per sow $(\geq 2$ $\mathrm{m}^{2}$ ). In the herds with concrete slats, the relative risk of claw infection was twice as high as in the herds with plastic slats, however the difference was not significant $(p>0.05)$. The lowest frequencies of claw infections were found among the youngest and oldest sows, however, these differences were not significant either (all the $95 \%$ CI overlap, Fig. 4). 


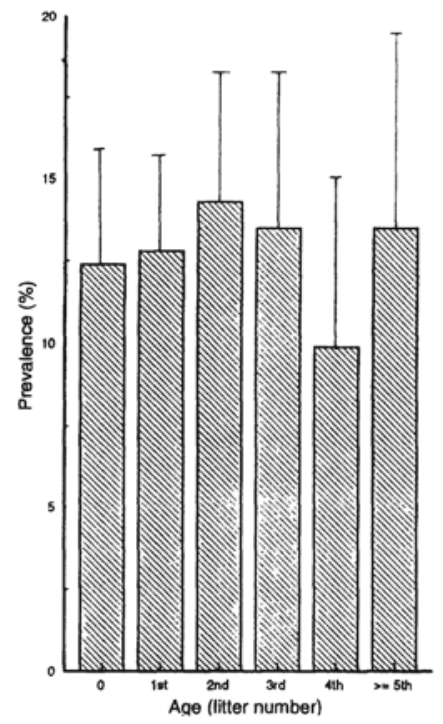

Figure 2. Mean prevalence proportion (with $95 \%$ $\mathrm{CI}$ ) of lame sows in relation to age (number of litters), loose herds (sow observations $n=1436$ ).

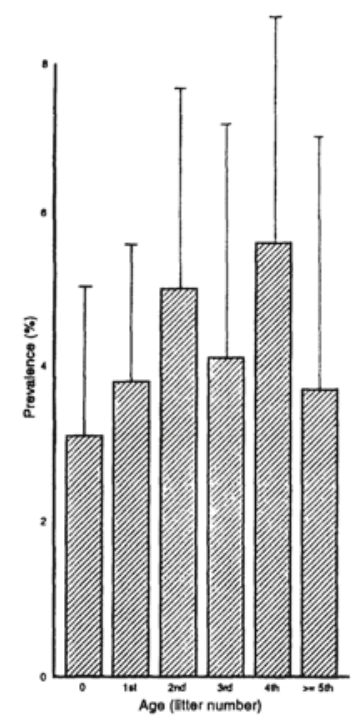

Figure 4. Mean prevalence proportion (with $95 \%$ $\mathrm{CI}$ ) of sows with claw infection in relation to age (number of litters) in loose herds (sow observations $\mathrm{n}=1436$ ).

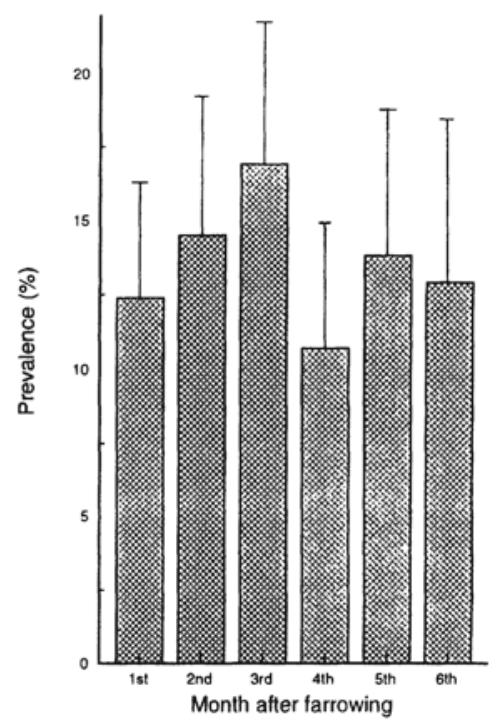

Figure 3. Mean prevalence proportion (with $95 \%$ $\mathrm{CI}$ ) of lame sows in relation to time after farrowing, loose herds (sow observations $n=1129$ ). 307 sows were not included in the figure, because 300 gilts had not farrowed, and 7 gilts had missing values.

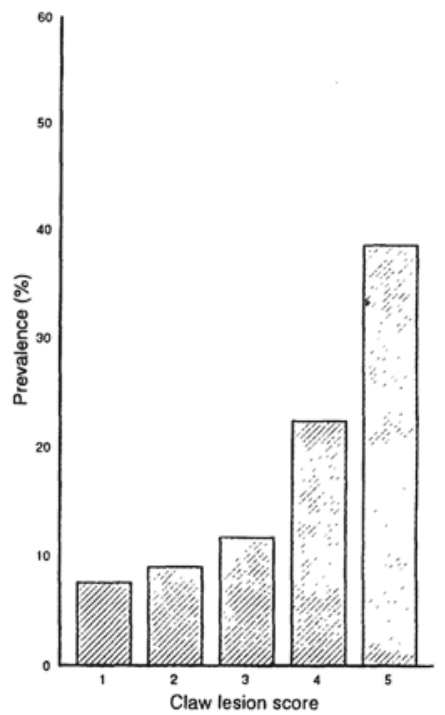

Figure 5. Mean prevalence proportion of lame sows in relation to maximum claw lesions score on the hind limbs of the loose sows (sow observations $\mathrm{n}=1436$ ). 
In 1 of the herds, 5 sows became paralyzed in the hind legs during the observation period. All these sows had abscesses in the vertebral column, and they also had claw infections that could have been the primary infection site. The sows had no other signs of infections.

\section{Relationship between lameness and claw lesions}

The occurrence and types of claw lesions have been described elsewhere (Gjein \& Larssen 1995 b, c).

In Fig. 5, all the observations of lame sows in the 3 examinations are distributed according to maximum claw lesion on the sow at that examination. The prevalence proportion of lameness increased with increasing claw score, especially on scores 4 and 5. This relationship is also demonstrated in Table 2 as a tendency to more lameness on legs with major claw lesions (score $\geq 3$ ) than on legs with minor or no claw lesions. However, this latter association was not statistically significant $(\mathrm{p}>0.05)$.

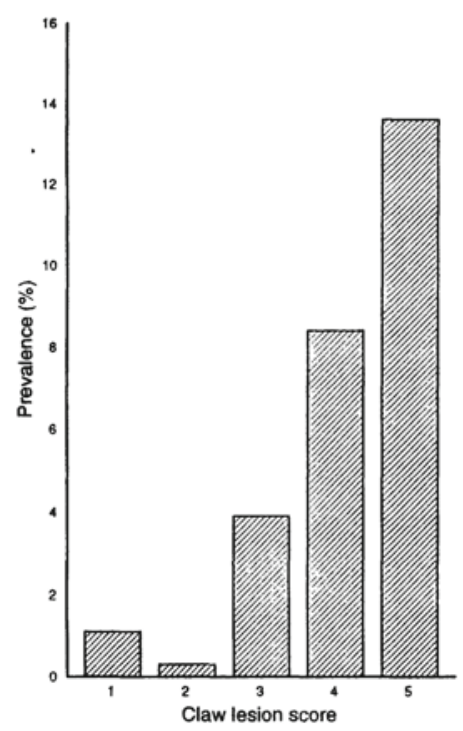

Figure 6. Mean prevalence of sows with claw infection in relation to maximum claw lesions score on the hind limbs of the loose sows (sow observations $\mathrm{n}=1436$ ).

Table 1. Lameness and claw infection in relation to environmental factors within loose herds $(n=15)$. Cumulative proportion of sows in each herd that were lame or had a claw infection on at least 1 of the 3 examinations.

\begin{tabular}{|c|c|c|c|c|c|c|c|}
\hline \multirow{2}{*}{$\begin{array}{l}\text { Environmental } \\
\text { factor }\end{array}$} & \multirow[t]{2}{*}{ No of herds } & \multicolumn{3}{|c|}{ Lameness } & \multicolumn{3}{|c|}{ Claw infection } \\
\hline & & Crude mean \% & LS-mean $\%{ }^{1)}$ & $\mathrm{RR}^{2)}$ & Crude mean $\%$ & LS-mean $\%$ & RR \\
\hline \multicolumn{8}{|c|}{ Floor hygiene: } \\
\hline - Poor & 7 & 25.0 & $20.4^{*}$ & 2.8 & 8.0 & $7.6^{*}$ & 4.2 \\
\hline - Medium & 4 & 21.8 & 21.7 & 3.0 & 5.7 & 5.7 & 3.2 \\
\hline - Good & 4 & 13.4 & $7.2 *$ & 1.0 & 1.7 & $1.8^{*}$ & 1.0 \\
\hline \multicolumn{8}{|c|}{ Area per sow : } \\
\hline$-<2 \mathrm{~m}^{2}$ & 4 & 24.9 & 16.9 & 1.1 & 9.3 & $6.8^{*}$ & 2.1 \\
\hline$-\geq 2 \mathrm{~m}^{2}$ & 11 & 19.7 & 16.0 & 1.0 & 4.4 & $3.2 *$ & 1.0 \\
\hline \multicolumn{8}{|l|}{ Slats : } \\
\hline - Concrete & 12 & 22.7 & $23.1^{*}$ & 2.4 & 6.1 & 6.7 & 2.0 \\
\hline - Plastic & 3 & 14.5 & $9.7^{*}$ & 1.0 & 4.0 & 3.3 & 1.0 \\
\hline All herds & 15 & 21.4 & - & - & 5.9 & - & - \\
\hline
\end{tabular}

1) The LS-mean is the mean when the confounding effect of the other environmental factors in the table had been accounted for.

2) Relative risks (RR) are based on LS-means.

* These groups were significantly different $(\mathrm{p}<0.05)$ from each other with regard to this environmental factor. 
Table 2. Lameness in relation to major claw lesions (score $\geq 3$ ) and claw infections in 15 loose herds.

\begin{tabular}{|c|c|c|c|c|c|c|c|c|c|c|c|}
\hline & & \multicolumn{5}{|c|}{ Lame - Left hind leg } & \multicolumn{5}{|c|}{ Lame - Right hind leg } \\
\hline & & Yes ${ }^{1)}$ & No & All & $\%$ & $\left.\mathrm{RR}(95 \% \mathrm{CI})^{2}\right)$ & Yes ${ }^{1)}$ & No & All & $\%$ & $\mathrm{RR}(95 \% \mathrm{CI})^{2)}$ \\
\hline Major claw & Yes ${ }^{1)}$ & 62 & 487 & 549 & 11.3 & $1.3(0.8-1.9)$ & 75 & 471 & 546 & 13.7 & $1.2(0.8-1.8)$ \\
\hline lesions & No & 27 & 272 & 299 & 9.0 & 1.0 & 34 & 268 & 302 & 11.3 & 1.0 \\
\hline Claw & Yes ${ }^{1)}$ & 12 & 13 & 25 & $48.0^{*}$ & $5.2(3.3-8.2)$ & 16 & 15 & 31 & $51.6^{*}$ & $4.5(3.0-6.6)$ \\
\hline infection & No & 75 & 734 & 809 & 9.3 & 1.0 & 93 & 710 & 803 & 11.6 & 1.0 \\
\hline
\end{tabular}

1) The sows were examined at 3 different times. For a sow to be in the "yes yes « group in the table both characteristics had to be present simultanously at least at 1 of the 3 examinations.

2) $\mathrm{RR}=$ Relative risk.

* Significantly more lame sows $(\mathrm{p}<0.05)$

The examination of the claws on all the lame sows showed that $65 \%$ of the sows had major claw lesions on the lame leg. However major claw lesions were also found on $57 \%$ of the legs of sows that were not lame.

\section{Relationship between lameness and claw infection}

There was a significantly $(\mathrm{p}<0.05)$ higher proportion of lameness on legs with claw infections than among the legs without claw infections (Table 2). Half of the sows with claw infections were lame, however, these sows counted for only $14 \%$ of all the lame sows.

\section{Relationship between claw infection and claw lesions}

In Fig. 6 all the observations of sows with claw infections at the 3 examinations are distributed according to the maximum claw lesion on the sow at that examination. The figure shows that the proportion of sows with claw infections increased with increasing claw score. This relationship is also present in Table 3 as a higher prevalence of claw infection on legs with major claw lesions than on legs with minor or no claw lesions, even though no statistically significant association $(p>0.05)$ was found for the right hind leg.

\section{Discussion}

This study showed that lameness was a clinical problem in herds with loose housing of sows on partly slatted floors. This observation agrees with other reports (de Koning 1990, van der Meulen et al. 1990, van der Wilt 1992).

There was increasing lameness with increasing

Table 3. Claw infection in relation to major claw lesions (score $\geq 3$ ) in 15 loose herds.

\begin{tabular}{|c|c|c|c|c|c|c|c|c|c|c|c|}
\hline & & \multicolumn{10}{|c|}{ Claw infection } \\
\hline & & \multicolumn{5}{|c|}{ Left hind leg } & \multicolumn{5}{|c|}{ Right hind led } \\
\hline & & Yes ${ }^{1)}$ & No & All & $\%$ & $\mathrm{RR}(95 \% \mathrm{CI})^{2)}$ & Yes $^{1)}$ & No & All & $\%$ & $\mathrm{RR}(95 \% \mathrm{CI})$ \\
\hline Major claw & Yes ${ }^{1)}$ & 23 & 522 & 545 & $4.2^{*}$ & $6.1(1.5-25.7)$ & 24 & 516 & 540 & 4.4 & $1.8(0.8-4.2)$ \\
\hline lesions & No & 2 & 287 & 289 & 0.7 & 1.0 & 7 & 280 & 287 & 2.4 & 1.0 \\
\hline
\end{tabular}

1) The sows were examined at 3 different times. For a sow to be in the "yes yes « group in the table both characteristics had to be present simultanously at least at 1 of the 3 examinations.

2) $R R=$ Relative risk.

* Significantly more lame sows $(\mathrm{p}<0.05)$ 
claw score. Two of 3 lame loose sows had major claw lesions, and sows with score 4 or 5 were especially prone to lameness. The corium contains numerous nerve fibres and is therefore sensitive to pain (Geyer \& Tagwerker 1986). A major claw lesion can thus produce lameness by itself from the pain of a deep injury or predispose to infections which subsequently cause lameness.

The prevalence proportion of lame sows was higher in the herds with concrete slats than in the herds with plastic slats. This may result from a higher physical stress to the claws on concrete slats than on the softer plastic slats. The frequency of major claw lesions was the same in herds with plastic and concrete slats (Gjein \& Larssen 1995 b).

The kind of floors and slats have great effect on foot health (Jensen 1979, Newton et al. 1980). The degree of lameness and claw lesions in loose housing of sows can thus be said to reflect the floor's quality. Partly or fully slatted floors with a minimum of straw bedding produce leg problems, and claw injuries may also be a serious problem (de Koning 1990, Svendsen et al. 1992). Other studies have shown that loose housed sows on a deep litter of straw generally show fewer injuries and less leg problems than sows fixed in crates or tethered (Svendsen et al. 1992).

Especially in loose housing, lameness can also result from acute lesions in the musculature, joints and bones when pigs newly introduced to a group fight to establish the rank order (Hill 1992). This is probably one important reason why the proportion of lame sows seemed to be highest in the second and third month after farrowing. The sows were introduced into the loose house compartment either directly after weaning (30-40 days after farrowing) or 3 weeks after breeding (60-70 days after farrowing).

It has been reported from Holland that lame- ness in group housing on partly slatted concrete floors in $75-90 \%$ of the cases was caused by claw lesions (Kroneman \& Vellenga 1991). The present study also found that most of the lame sows had claw lesions, although among sows without any lameness, there was also a high proportion of sows with major claw lesions. The finding of a claw lesion on a lame sow did not necessarily mean that the lesion caused the lameness. Only a small proportion (11-13\%) of the sows with major claw lesions was lame on the same leg as the claw lesion was found. Similarly, van der Wilt et al. (1992) did not find a correlation between lameness and claw lesion at the same leg. However, when looking at the sows in the present study with the most serious claw lesions (score $=5$ ), nearly $40 \%$ of these sows were lame.

A sow with a claw infection was more likely to be lame than a sow without a claw infection. This is due to the pain the inflammation produces in the claw. Nevertheless, a large number of the sows with claw infections was not lame. The reason for this might be that the infection was chronic and no longer painful, i.e. sows were lame only in the acute stage of the inflammation. The inflamed corium in the claw has been shown to produce horn of a lower quality and less resistant to injury (Kovacs \& Somogyvari 1975). This may increase the risk of lameness after the infection as such is healed.

The sows with major claw lesions seemed to be more subject to a claw infection than sows with minor claw lesions, however, the great variation in prevalence of claw infections from herd to herd can not be explained by difference in prevalence of claw lesions only.

The general standard of management within a herd determines to which extent a claw lesion may lead to infection (Simmins \& Brooks 1988). The herds with poor floor hygiene, i.e. most of the floor was covered with faeces and urine, had a high proportion of lame sows and 
sows with claw infection. When pregnant sows were stalled in the same pen and walked in faeces and urine, pathogens could easily be transferred from sow to sow. Small area per sow also seemed to predispose to claw infection. This could be due to difficulties in keeping the crowded pens clean or to the fact that there was more fighting among the sows in these pens. The design of this study was not optimal to assess the dynamic interrelationship between lameness, claw lesions and infection. A cohort study with more frequent visits would have been better. Also the power in detecting statistically significant associations is small with so few herds. There is a risk of not detecting associations that really exist. More research is needed to clarify the influence of claw lesions on lameness in sows.

\section{Conclusions}

Serious claw lesions and claw infections were risk factors for lameness. The claw lesions of lower score did not cause lameness. In loose housing poor floor hygiene and low area per sow $\left(<2 \mathrm{~m}^{2}\right)$ increase the prevalence of claw infection. Concrete slats increase the prevalence of lameness.

\section{Acknowledgement}

We thank Nina Lunderød for excellent technical assistance.

\section{References:}

Dagorn J, Aumaitre A: Sow culling; reasons for and effect on productivity. Livest. Prod. Sci. 1979, 6, 167-177.

D'Allaire S, Stein TE, Leman AD: Culling patterns in selected Minnesota swine breeding herds. Can. J. vet. Res. 1987, 51, 506-512.

Dean AG, Dean JA, Burton AH, Dicker RC: Epi Info, Version 5; a word processing, database, and statistics program for epidemiology on micro-computers. Usd, Inc., Stome Mountain, Ga. 1990.

de Koning R, Backus GBC, Vermeer HM: Welfare, behaviour, and performance; partly slatted systems. Electronic identification in pig production; an international symposium exchanging experience between countries. Stoneleigh, 1990, 53-62.

Dewey CE, Friendship RM, Wilson MR: Lameness in breeding age swine - a case study. Canad. vet J. 1992, 33, 747-748.

Fritschen RD: Housing and its effect on feet and leg problems. Proc. pig vet. Soc. 1979, 5, 95-98.

Geyer H, Tagwerker F: The pig's hoof; its structure and alterations. Hoffmann La Roche, Basel, 1986, 1-27.

Gjein H, Larssen RB: Housing of pregnant sows in loose and confined systems - a field study. 1 . Vulva and body lesions, culling reasons and production results. 1995a. Acta vet. scand. 1995, 36, 185-200.

Gjein H, Larssen RB: Housing of pregnant sows in loose and confined systems - a field study. 2 . Claw lesions: morphology, location and relation to age. Acta vet. scand. 1995b, 36, 433-442.

Gjein H, Larssen RB: Housing of pregnant sows in loose and confined systems - a field study. 3 . The impact of housing factors on claw lesions. Acta vet. scand. 1995c, 36, 443-450.

Hill MA: Skeletal system and feet. In: Leman AD, Straw BE, Mengeling WL, D'Allaire S, Taylor DJ, (eds): Diseases of swine. 7th ed. Iowa State University Press, Ames, Iowa, 1992, 163-195.

Hoskin BD: Foot abscesses in pigs. Vet. Rec. 1965, 77, p. 1048.

Jensen $A H$ : The effects of environmental factors, floor design and materials on performance and on foot and limb disorders in growing and adult pigs. Proc pig vet. Soc. 1979, 5, 85-94.

Karlberg $K$ : Utrangeringsårsaker hos avlspurker (Reasons for culling of sows). Norsk Vet.- T. 1979, 91, 423-426.

Kovacs AB, Somogyvari K: Histological structure of hoof keratin and corium in swine, and features of keratinization. Vet. Bull. 1975, 45, Abstr. 2903.

Kroneman $A$, Vellenga $L$ : Field survey on veterinary problems in group-housed sows; a survey on lameness. Proc. 42nd Ann. Meet. Europ. Ass. Anim. Prod., Berlin, 1991, p.359.

Newton GL, Booram CV, Hale OM, Mullinix jr BG: Effects of four types of floor slats on certain feet characteristics and performance of swine. J. Anim. Sci., 1980, 50, 7-20.

Penny RHC, Osborne AD, Wright AI: The causes and incidence of lameness in store and adult pigs. Vet. Rec. 1963, 75, 1225-1240. 
Penny RHC, Osborne AD, Wright AI, Stephens TK: Foot-rot in pigs: Observations on the clinical disease. Vet. Rec. 1965, 77, 1101-1108.

SAS (Institute Inc.): System version 6.04 for DOS. SAS Institute Inc., Cary, NC, 1989.

Simmins PH, Brooks PH: Supplementary biotin for sows; effect on claw integrity. Vet. Rec. 1988, 122, 431-435.

Svendsen J, Olson AC, Svendsen L: Group housing systems for sows. 3 . The effect on health and reproduction. A literature review. Swedish J. agric. Res. 1992, 22, 171-180.

van der Meulen HPA, Burè RG, Koning de R, Vellenga $L$ : Oriënterend ond erzoek naar kreupelheid bij zeugen in groepshuisvesting (Preliminary research into lameness in group-housed sows). Instituut voor Mechanisatic, Arbeid en Gebouwen, Wageningen, 1990, Rapport 232.

van der Wilt FJ, Vellenga L, Vermeer HM, Kroneman $A$ : Lameness and claw lesions in group-housed sows. Proc. $12^{\text {th }}$ Congr. Int. Pig vet. Soc. The Hague, 1992, 12, p. 536.

Wright AI, Osborne AD, Penny RHC, Gray EM: Foot-rot in pigs; experimental production of the disease. Vet. Rec. 1972, 90, 93-99.

\author{
Sammendrag \\ Effekten av klauvskader og klauvinfeksjoner på halt- \\ het hos drektige purker i løsdrift.
}

En feltundersøkelse ble i løpet av ett år gjennomført i 15 besetninger med løsgående purker. Alle besetningene hadde betonggulv med spalter på ca. en tredel av arealet. Tolv besetninger hadde betongspalter mens 3 besetninger hadde plastspalter. Den gjennomsnittlige prevalensen av halte purker $i$ besetningene var $13.1 \%$ og av purker med klauvinfeksjon $3.8 \%$. Risikoen for halthet økte med økende klauvskade score og hvis det var infeksjon i klauvskaden. Purker som ble holdt på betongspalter, hadde høyere risiko for å fă klauvinfeksjoner og for å bli halte enn purker som gikk på plastspalter. I besetninger med dårlig renhold og lite strø var risikoen for klauvinfeksjoner og halthet størst. Det var størst risiko for klauvinfeksjoner i besetninger med lite areal $\left(<2 \mathrm{~m}^{2}\right)$ per purke.

(Received June 1, 1994; accepted June 16, 1995).

Reprints may be obtained from: H. Gjein, Central Veterinary Laboratory, P.O. Box 8156, Dep. N-0033 Oslo, Norway. 
